\title{
Synergistic Combination of Ciplukan (Physalis angulata) Herbs Ethanolic Extract and Doxorubicin on T47D Breast Cancer Cells
}

\author{
Inna Armandari, Kartika Dyah Palupi, Sofa Farida, Adam Hermawan, Ratna \\ Asmah Susidarti and Edy Meiyanto* \\ Cancer Chemoprevention Research Center \\ Faculty of Pharmacy, Universitas Gadjah Mada, Yogyakarta
}

\begin{abstract}
Doxorubicin is one of chemotherapeutic agent widely used in breast cancer treatment, but in high dose doxorubicin gives negative side effect, including vomit, nausea, immune suppression, and cardiac toxicity. This toxicity hopefully could be reduced by combination chemotherapy using natural herbs such as ciplukan herb. This research was conducted to explore cytotoxic activity of single ciplukan herbs ethanolic extract and its combination with doxorubicin on T47D breast cancer cells. Cytotoxic activity of ciplukan herbs ethanolic extract only and its combination with doxorubicin were tested on T47D cells using MTT assay to obtain IC50 value and combination index $(\mathrm{Cl})$, respectively. Single extract showed cytotoxic activity on T47D cells with IC50 value of was $160 \mu \mathrm{g} / \mathrm{ml}$. Thus, combination treatment from ciplukan herbs ethanolic extract and doxorubicin showed synergistic effect $(\mathrm{Cl}<1,0)$. This effect was reached at concentration of ciplukan herbs ethanolic extract-doxorubicin $80 \mu \mathrm{g} / \mathrm{ml}-2 \mathrm{nM}$, $80 \mu \mathrm{g} / \mathrm{ml}-4 \mathrm{nM}$, and $80 \mu \mathrm{g} / \mathrm{ml}-8 \mathrm{nM}$. This research indicated that ciplukan herbs ethanolic extract is potential to be applied as co-chemotherapeutic agent in breast cancer therapy.
\end{abstract}

Keywords : ciplukan herbs, doxorubicin, co-chemotherapy, T47D cells.

\section{INTRODUCTION}

As a high breast cancer occurences in the world, scientist are exploring and improving the best way to heal breast cancer. Doxorubicin (doxo) is one of chemotherapeutic agent widely used in the breast cancer therapy. However, therapy with doxo is limited because of its systemic toxicities, mainly cardiac toxicity, immune suppression (Wattanapitayakul et al., 2005), drug resistance (Davis et al., 2003), and apoptotic failure of cancer cells (Notarbartolo et al., 2005). Another side effects from doxo which often happened in therapy are vomit, nausea, hair loss. Combination chemotherapy is one of some approaches which can be applied to suppress doxo side effects. In combination chemotherapy, non-toxic or less toxic phytochemicals is combined with chemotherapeutics agents to enhance the efficacy together with a reduced toxicity to normal tissues (Sharma et al., 2004; Tyagi et al., 2004).

Ciplukan (Physalis angulata) is one of natural herbs which exhibited cytotoxic activity on several cancer cells, including leukimia cells P388, nasopharing cancer cells KB-16, and lung cancer cells A-549 (Ismail and Alam, 2001). Wu et al. (2004) reported that ethanolic extract of $P$. angulata and $P$. peruviana had cytotoxic activity againts Hep G2 liver cancer cells.

Physalis angulata herbs methanolic extract inhibited cell cycle progression by arresting cell at $\mathrm{G} 2 / \mathrm{M}$ phase and inducing apoptosis on MCF-7 as well as MDA-MB 231 breast cancer cells (Hsieh et al., 2006). Physalis angulata also had been described contain some active compounds such as saponin, flavonoid, polyphenols, and steroid (Shingu et al., 1992). One of its active compounds is physalin. It is a seco steroid which could decrease pro-inflamatory cytokines production (Soares et al., 2005). Furthermore, from in vitro and in vivo studies, physalin B and physalin D showed strong cytotoxic activity and antiproliferative effect (Magalhães et al., 2006).

*Corresponding author e-mail : meiyan_e@ugm.ac.id 
This study is aimed to evaluate synergistic effect of ciplukan (Physalis angulata) herbs ethanolic extract (EC) in combination with doxorubicin on T47D breast cancer cells. Hopefully, the outcomes of this study will give information in the development of breast cancer therapy.

\section{METHODOLOGY}

\section{Ciplukan herbs ethanolic extract (EC) preparation}

Health, green, and 30-40 cm height ciplukan herbs were harvested from Besi, Sleman, Yogyakarta. The whole part of ciplukan herbs was used to produce ethanolic extract. Ciplukan herbs were collected and dried using oven under temperature $40^{\circ} \mathrm{C}$. Dried herbs was then powderized with blender (National) and extracted using ethanol $70 \%$ (Merck). Rotary evaporation (Heidolp WB 2000) was done to concentrate ciplukan herbs ethanolic extract (EC).

\section{T47D cells culture}

T47D cell line-was obtained from Cancer Chemoprevention Research Centre (CCRC), and it was gained from Prof. Tatsuo Takeya (Nara Institute of Science and Technology, Japan). T47D cells were grown in Dulbecco's modified Eagle's Medium (DMEM; Gibco), 10\% fetal bovine serum (FBS; Gibco), and 1\% Penicillin-Streptomycin (Gibco). The cells were incubated under temperature $37^{\circ} \mathrm{C}$ and $5 \% \mathrm{CO}_{2}$.

\section{Cytotoxic assay using MTT}

T47D were seeded in 96-well plates (Iwaki) with $5 \times 10^{3}$ cells/well and divided into control and treatment group. Single serial dilution of EC at 1, $10,50,100,250,500,750,1000 \mu \mathrm{g} / \mathrm{ml}$. EC (5 mg) was dissolved in Dimethyl sulfoxide (DMSO) as stock solution $(1 \mathrm{mg} / \mathrm{ml})$ then diluted in culture medium until desired concentration. After $24 \mathrm{~h}$ incubation, culture medium was removed and cells were washed using PBS (Sigma). $5 \mathrm{mg} / \mathrm{ml}$ of MTT (Sigma) was diluted by culture medium $(1 \mathrm{ml}$ MTT stock add $10 \mathrm{ml}$ culture medium) and $100 \mu \mathrm{l}$ of it was added into every well. Then, the plate was incubated for 2-4 $\mathrm{h}$ until formazan was produced. MTT reaction was stopped by Sodium Dodecyl Sulfate (SDS) $10 \%$ in HCL $0,1 \mathrm{~N}$ (Merck). The plate was then covered with paper or aluminum foil and incubated in a dark place overnight, followed by incubation, shake for 10 minutes and measured the absorbance using ELISA reader (Bio-Rad) at wave length of 595 $\mathrm{nm}$. The concentration applied on single agent was referred to $\mathrm{IC}_{50}$ value. Cytotoxic activity of doxorubicin was determined using MTT assay in previous study. Doxorubicin showed cytotoxic activity on T47D cells with $\mathrm{IC}_{50}$ value $16 \mathrm{nM}$ (Fitriasari et al., 2009)

\section{Combination Index $(\mathrm{Cl})$ analysis.}

The CI was used to analyze synergistic, additive, or antagonistic effect of different drugs combinations (Zhao et al., 2004; Reynolds and Maurer, 2005). Briefly, variable rations of EC concentration e.g. $20,40,60,80 \mu \mathrm{g} / \mathrm{ml}$ with 2,4 , $6,8 \mathrm{nM}$ doxo, were used to treat T47D cells for 24 h. Cells viability were detected by MTT assay as describe above on cytotoxic assay. Then data was analyzed using mutually exclusive equation to determine the CI. Each CI was calculated from the mean affected fraction at each EC ratio concentration using Chou and Talalay equation (1984); CI $>1, \quad \mathrm{CI}=1, \quad$ and $\quad \mathrm{CI}<1$ indicated antagonistic, additive, and synergistic effect respectively (Zhao et al., 2004; Reynolds and Maurer, 2005).

\section{Statatistical analysis.}

Absorbance data from cytotoxic assay were analyzed by Excell MS Office 2003 and semi-log analysis (SPSS 11.5) to obtain $\mathrm{IC}_{50}$ value. One way Anova was used to assess concentration $(\mathrm{p}<0.05)$ and post-hoc comparissons were made using Tukey's significant different test.

\section{RESULT AND DISCUSSION}

\section{Cytotoxic effect of ciplukan herbs ethanolic extract on T47D cells}

MTT assay was used to explore the effect of single treatment EC on T47D cells. The absorbance obtained from MTT assay is equal to T47D cells viability. Cytotoxic activity was presented by $\mathrm{IC}_{50}$ value. $\mathrm{IC}_{50}$ is a concentration where EC inhibit $50 \%$ of cell population. Single treatment of EC had cytotoxic activity on T47D cells with $\mathrm{IC}_{50}$ value $160 \mu \mathrm{g} / \mathrm{ml}$ (Figure 1). 


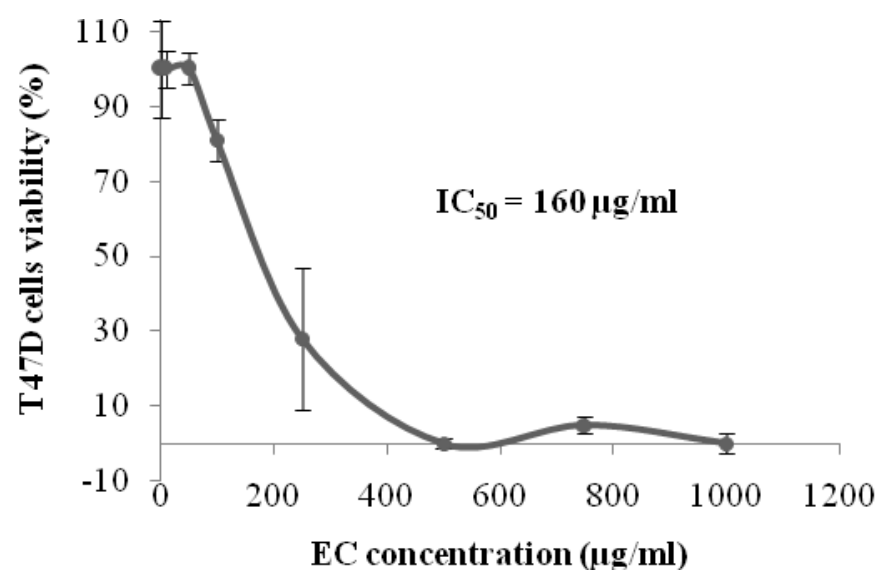

Figure I. Ethanolic Extract (EC) effect on T47D cells viability. EC reduced T47D cells viability in dose dependent manner. T47D cells were incubated with EC at concentration I, 10, 50, 100, 250, 500,750 , and $1000 \mu \mathrm{g} / \mathrm{ml}$ during $24 \mathrm{~h}$ on temperature $37{ }^{\circ} \mathrm{C}$. T47D cells viability was measured using MTT assay. IC 50 value was $160 \mu \mathrm{g} / \mathrm{ml}$. Data shown was obtained from 3 replication, $\overline{\mathrm{X}} \pm \operatorname{SD}(\mathbf{p}<0,05)$.

\section{Combination effect of EC and doxo on T47D cells.}

Combination effect of EC-doxo was determined by MTT assay as described previously. $\mathrm{EC}$ and doxo concentration used in treatment was $20,40,60,80 \mu \mathrm{g} / \mathrm{ml}$ and $2,4,6,8 \mathrm{nM}$, respectively. The result of combination treatment was performed using combination index (CI). Cytotoxic effect of EC-doxo combinations on T47D cells could be seen from their morphology under inverted microscope after $24 \mathrm{~h}$ treatment (Figure 2). T47D cells control was shown on figure 2A. It had regular morphology and well growth. Single treatment of EC at concentration of $80 \mu \mathrm{g} / \mathrm{ml}$ (figure 2B) showed different morphology compared to control cells. Morphology changing of T47D cells also happened in the treatment of single doxo at concentration of $4 \mathrm{nM}$ (figure 2C). However, there were some cells had the same morphology as the cells control. Combinational treatment of EC-doxo at concentration $80 \mu \mathrm{g} / \mathrm{ml}-4$ $\mathrm{nM}$ respectively made significant changing of T47D morphology compared to the cells control. The mortality of T47D cells were indicated as a round in shape cells which indicated mortality. 


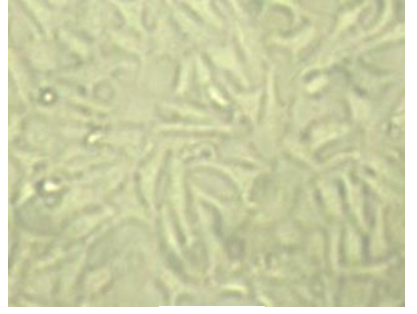

A

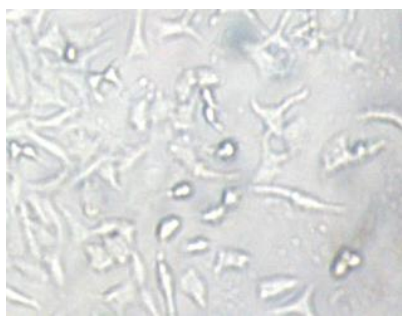

C

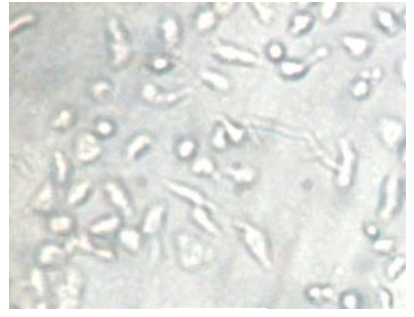

B

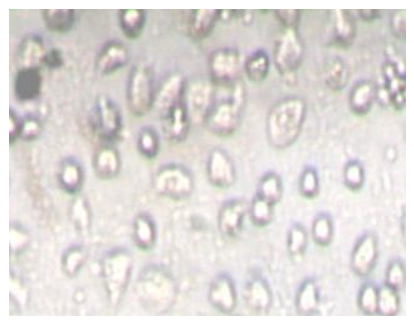

D

Figure 2. EC-doxo combination effect on T47D cells morphology. Combination of EC-doxo could change T47D cells morphology. (A) T47D cell control; (B) EC single treatment at concentration 80 $\mu \mathrm{g} / \mathrm{ml}$; (C) doxo single treatment at concentration $4 \mathrm{nM}$; (D) EC-doxo combination treatment at concentration $80 \mu \mathrm{g} / \mathrm{ml}-4 \mathrm{nM}$. T47D cells observation was performed using inverted microscope under 400x magnification.

T47D viabilty after $24 \mathrm{~h}$ combination treatment of EC-doxo presented in figure 3A. Cells viability decreased as increasing concentration of EC. It could be described that EC had strong influence on cell viability. T47D cells viability was $99,2 \%$ and
$54,18 \%$ because of single treatment doxo $4 \mathrm{nM}$ and EC $80 \mu \mathrm{g} / \mathrm{ml}$ respectively. Then, treatment combination obtained $40,69 \%$ cells viability at same concentration. Further confirmation of this result was shown using CI (Figure 3B).
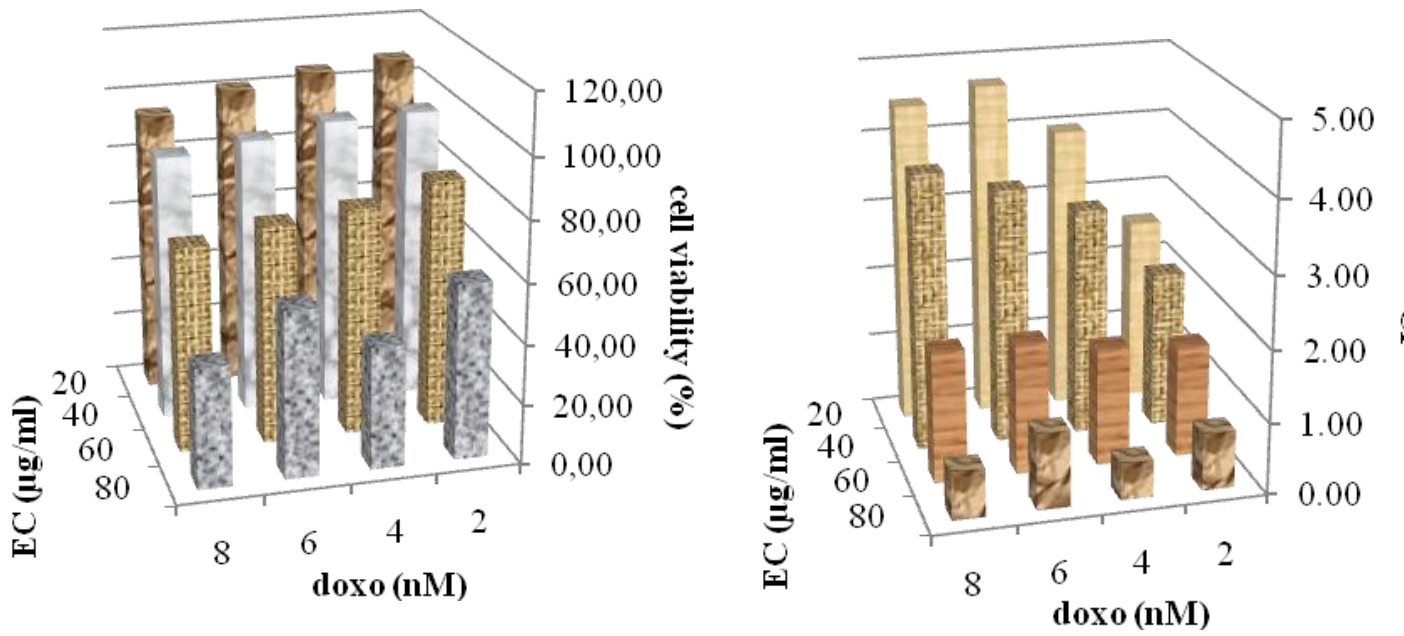

Figure 3. Combination effect of EC-doxo on T47D cells. (A) Combination effect of EC-doxo treatment on T47D cells viability at different concentration; (B) $\mathrm{Cl}$ calculation based on Chou and Talalay equation. EC-doxo combination gives synergistic effect on T47D cells. 
CI calculation (Table 1) resulted that combination EC-doxo showed synergistic effect at concentration EC-doxo $80 \mu \mathrm{g} / \mathrm{ml}-2 \mathrm{nM}, 80 \mu \mathrm{g} / \mathrm{ml}$ $4 \mathrm{nM}$, dan $80 \mu \mathrm{g} / \mathrm{ml}-8 \mathrm{nM}$. These concentration obtained CI value under 1,0 which indicated synergistic effect. At low EC concentration, CI value was above 1,0 which indicated antagonist effect. As an increasing concentration of EC combined with doxo, CI value decreased. All results above indicated that EC could increased doxo effication on T47D cells, it suggested that the proper combination of these agents are potential benefits in treating breast cancer. Furthermore, advance research is needed to confirm this result, especially in vivo studies.

Table I. Combination index $(\mathrm{Cl})$ value of combination EC-doxo on T47D cells

\begin{tabular}{|c|c|c|c|c|}
\hline \multirow{2}{*}{$\begin{array}{c}\text { EC concentration } \\
(\mu \mathrm{g} / \mathrm{ml})\end{array}$} & \multicolumn{4}{|c|}{ doxo concentration $(\mathrm{nM})$} \\
\hline & $2\left(I / 8 I C_{50}\right)$ & $4\left(I / 4 \mid C_{50}\right)$ & $6\left(3 / 8 \mid C_{50}\right)$ & $8\left(I / 2 I C_{50}\right)$ \\
\hline $20\left(\mathrm{I} / 8 \mathrm{I} \mathrm{C}_{50}\right)$ & 2.58 & 3.98 & 4.70 & 4.49 \\
\hline $40(\mathrm{I} / 4 \mathrm{IC} 50)$ & 2.19 & 3.19 & 3.56 & 3.87 \\
\hline $60\left(3 / 8 I_{50}\right)$ & 1.56 & 1.64 & 1.83 & 1.83 \\
\hline $80(\mathrm{I} / 2 \mathrm{IC} 50)$ & 0.80 & 0.52 & 1.06 & 0.67 \\
\hline
\end{tabular}

Doxorubicin is a chemotherapeutic agent which damaged double stranded DNA because of by intercalation on DNA base pairs and inhibition of topoisomerase II $\alpha$. DNA damage will activate kinase protein (ATM), and this will further which activate Chk2. Activation of Chk2 will make cdc25 inactive and cause inhibition of cdc2. Both proteins are needed in $\mathrm{G}$ and $\mathrm{M}$ phase of cell cycle. Inactivation of these proteins will lead $\mathrm{G} 2 / \mathrm{M}$ arrest in cell (Drummond, 2007). G2/M arrest because of single doxo will be stronger when it was combined with EC.

Hsieh et al. (2006) reported that $P$. angulata methanolic extract inhibit proliferation and induce apoptosis of MDA-MB 231 cancer cells. These effects happened trough the inhibition of cyclin Bcdc2 complex protein. The other mechanism related to inhibition of cyclin B-cdc2 complex protein is higher level of $\mathrm{p} 27^{\mathrm{kip} 1}$ protein. Inhibition of cyclin B-cdc2 complex protein will lead to G2/M arrest (Ismail and Alam, 2001).

However, There were few studies which reported the apoptosis induction caused by because of $P$. angulata and related studies reported apoptosis effect because of Physalin sp. Chloroform extract of $P$. minima $\mathrm{L}$. found to increased p53 and caspase-3 mRNA on NCI-H23 cells (Leong et al., 2009) which caused induced apoptosis (Salvensen and Riedl, 2008). Water extract of $P$. peruviana was also found to increased the production of intracellular reactive oxygen species (ROS) such as hydrogen peroxide $\left(\mathrm{H}_{2} \mathrm{O}_{2}\right)$, which had pro-oxidant activity (Hsieh et al., 2006). High production of $\mathrm{H}_{2} \mathrm{O}_{2}$ would damage lipid, protein, as well as DNA and led to apoptosis process (Gosslau and Rensing, 2002). Taken together, combination of EC-doxo gave synergistics effect on T47D cells may because they have similar mechanism, trough cell cycle inhibition on $\mathrm{G} 2 / \mathrm{M}$ phase and apoptosis induction. It is important to note that this mechanism is only the prediction based on the existing results at present and requires further more studies, like such as immunocytochemistry (ICC) and western blot to explore related protein in cell cycle and apoptosis. The positive outcomes of these studies still warrant further in vivo studies in pre-clinical breast cancer models to develop Ciplukan as a candidate for combinational therapy with doxo.

\section{CONCLUSION}

The conclusion of this study showed that combination between EC-doxo gave synergistic effect on T47D breast cancer cell, suggests that the proper combination of EC-doxo is potential benefits in treating breast cancer.

\section{REFERENCES}

Chou, T.C. and Talalay, P., 1984, Quantitative analysis of dose effect relationship: The combined effect of multiple drugs or enzyme inhibitors, Adv Enzyme Regul., 22, 27-55.

Davis, J.M., Navolonic, P.M., Weinstein, C.R., Steelman, L.S., Hu, Konovlepa, M., Blagosklonny, M.V. and McCubrey, J.A., 2003, Raf-I and Bcl-2 induce distinct and common pathway that contribute to cancer drug resistance, Clin Cancer Res., 9, I|6I-II70. 
Drummond, C, 2007, The mechanism of antitumour activity of the DNA binding agent SN 28049, Thesis. New Zealand: University of Auckland.

Fitriasari, A., Junedi, S., Hermawan, A., Susidarti, R.A. and Meiyanto, E., 2009, Induction of apoptosis and cell cycle arrest by naringenin to increase the cytotoxic activity of doxorubicin on breast cancer cell lines, The International Conference on Pharmacy and Advance Pharmaceutical Science, 124.

Gosslau, A. and Rensing, L., 2002, Oxidative Stress, Age-dependent cell damage and antioxidative mechanism, Zeitschrift fur Gerontologie und Geriatrie, 35, I39-I50.

Hsieh, W.T., Huang, K.Y., Lin, H.Y. and Chung, J.G., 2006, Physalis angulata induced G2/M phase in human breast cancer cells, Food Chem Toxicol., 4, 974-983.

Ismail, N. and Alam, M., 200I, A novel cytotoxic flavonoid glycosides from Physalis angulate, Fitoterapia, 72, 676-679.

Leong, O.K., Sifzizul, T., Muhammad, T. and Sulaiman, S.F., 20II, Cytotoxic activities of Physalis minima L. chloroform extract on human lung adenocarcinoma $\mathrm{NCl}-\mathrm{H} 23$ cell lines by induction of apoptosis. Evid Based Complement Alternat Med., 20 I I, I10.

Magalhaes, H.I., Veras, M.L., Torres, M.R., Alves, A.P., Pessoa, O.D., Silveira, E.R., CostaLotufo, L.V., de Moraes, M.O. and Pessoa, C., 2006, In-vitro and in-vivo antitumour activity of Physalins B and D from Physalis angulate, J Pharm Pharmacol., 58(2), 235241.

Notarbartolo, M., Poma, P., Perri, D., Dusonchet, L., Cervello and Alessandro, N., 2005, Antitumor effect of curcumin, alone or in combination with cisplatin or doxorubicin on human hepatic cancer cell: Analysis of their possible relationship to changes in NF-kB activation levels and in IAP gene expression, Canc Lett., 224, 53-65.

Reynolds, C.P. and Maurer, B.J., 2005, Evaluating response to antineoplastic drug combination in tissues culture models, Method Mol Med., I I 0, 173-83.

Salvensen, G.S. and Riedl, S.J., 2008, Caspase mechanism, Adv Exp Med Biol., 6I 5, I3-23.

Sharma, G., Tyagi, A.K., Singh, R.P., Chan, D.C.F. and Agarwal, R., 2004, Synergistic Anticancer effect of grape seed extract and conventional cytotoxic against human breast cancer carcinoma cells, Breast Cancer Res Treat, 85, I-12.

Shingu, K., 1992, Three new Withanolides, Physagulins $E, F$ and $G$ from Physalis angulata L., Chem Pharm Bull., 40, 24482451.

Soares, M.B.P., Brustolim, D., Santos, L.A., Bellintani, M.C., Paiva, F.P., Ribeiro, Y.M. and Tomassini, T.C.B., 2005, Physalins B, $F$ And G, Seco-Steroids purified from Physalis angulata L. inhibit lymphocyte function and allogeneic transplant rejection, Int Immunopharmacol., 6(3), 408-4I4.

Tyagi, A.K., Agarwal, C., Chan, D.C.F. and Agarwal, R., 2004, Synergistic anti-cancer effect of Silibilin with conventional cytotoxic agents Doxorubicin, Cisplatin and Carboplatin against human breast cancer carcinoma MCF-7 and MDAMB468 cells, Oncol Rep., I (2), 493-499.

Wattanapitayakul, S.K., Chularojmontri, L., Herunsalee, A., Charuchongkolwongse, S., Niumsakul, S. and Bauer, J.A., 2005, Screening of antioxidant from medicinal plants for cardioprotective effect against Doxorubicin toxicity, Basic Clin Pharmacol Toxic., 96(I), 80-87.

Wu, S.J., Ng, L.T., Chen, C.H., Lin, D.L., Wang, S.S. and Lin, C.C., 2004, Antihepatoma activity of Physalis angulata and Physalis peruviana extracts and their effects on apoptosis in human Hep G2 cells, Life Sci., 74, 206 I-2073.

Zhao, L, Wientjes, M.G. and Au, J.L.S., 2004, Evaluation of combination chemotherapy: Integration of nonlinier regression, curve shift, isobologram, and combination index analyses, Clin Canc Res., 10, 7994-8004. 